\title{
Life Cycle Carbon Benefits of Aerospace Alloy Recycling
}

\author{
Matthew J. Eckelman ${ }^{\mathrm{a}}$, Luca Ciacci ${ }^{\mathrm{b}}$, Goksin Kavlak ${ }^{\mathrm{c}}$, Philip Nuss ${ }^{\mathrm{b}}$, Barbara K. Reck ${ }^{\mathrm{b}}$, T.E. \\ Graedel $^{\mathrm{b}}$ \\ ${ }^{\text {a }}$ Department of Civil and Environmental Engineering, Northeastern University, 360 Huntington Avenue, \\ Boston, MA 02115, USA (corresponding author) \\ ${ }^{\mathrm{b}}$ Center for Industrial Ecology, Yale University, 195 Prospect Street, New Haven, CT 06511, USA \\ ${ }^{c}$ Engineering Systems Division, Massachusetts Institute of Technology, 77 Massachusetts Avenue, \\ Cambridge, MA 02139, USA
}

This document is the Accepted Manuscript version of a Published Work that appeared in final form in the Journal of Cleaner Production after peer review and technical editing by the publisher. To access the final edited and published work see:

http://www.sciencedirect.com/science/article/pii/S0959652614005071

Please cite as:

Eckelman, M.J., Ciacci, L., Kavlak, G., Nuss, P., Reck, B.K., Graedel, T.E., 2014. Life cycle carbon benefits of aerospace alloy recycling. Journal of Cleaner Production 80, 38-45. doi:10.1016/j.jclepro.2014.05.039

(C) 2014. This manuscript version is made available under the CC-BY-NC-ND 4.0 license http://creativecommons.org/licenses/by-nc-nd/4.0/ 


\title{
Life Cycle Carbon Benefits of Aerospace Alloy Recycling
}

\author{
Matthew J. Eckelman ${ }^{\mathrm{a}}$, Luca Ciacci ${ }^{\mathrm{b}}$, Goksin Kavlak ${ }^{\mathrm{c}}$, Philip Nuss ${ }^{\mathrm{b}}$, Barbara K. Reck ${ }^{\mathrm{b}}$, T.E. \\ Graedel $^{\mathrm{b}}$ \\ ${ }^{a}$ Department of Civil and Environmental Engineering, Northeastern University, 360 Huntington Avenue, \\ Boston, MA 02115, USA (corresponding author) \\ ${ }^{\mathrm{b}}$ Center for Industrial Ecology, Yale University, 195 Prospect Street, New Haven, CT 06511, USA \\ ${ }^{\mathrm{c}}$ Engineering Systems Division, Massachusetts Institute of Technology, 77 Massachusetts Avenue, \\ Cambridge, MA 02139, USA
}

\begin{abstract}
The goal of this project is to determine the reductions in greenhouse gas (GHG) emissions associated with the recycling of aerospace alloys. This study is based on an aerospace recycler that sells much of its high-performance alloy scrap directly to remelters that produce these alloys for aircraft engine component manufacturers, with significant potential environmental benefits arising from the substitution of recycled materials for virgin materials. The project team explored existing sources of environmental data for all of the metals that make up aerospace alloys, and ten common alloys were chosen as case studies. Certain metal elements, including niobium, rhenium, tungsten, and zirconium, did not have any robust environmental impact information, and for these GHG emissions factors from primary production were modeled using a variety of statistical and industrial data sources. The project team then investigated the forms of metal inputs into alloying operations to ensure that the model reflects actual industrial practices and that the alloy scrap substitutes for virgin materials. GHG emissions are also incurred through alloy scrap collection and processing, and so a carbon footprint was performed for alloy recycling operations in order to determine these burdens. Overall, the recycling of aerospace alloys for reuse in the aerospace industry represents significant reductions in GHG emissions for each of the ten alloys considered, while emissions associated with collection and processing are $<5 \%$ in comparison . Certain elements occur in small quantities in alloys, such as rhenium (Re) and tantalum (Ta), but due to their high carbon intensity they are very significant in the final results.
\end{abstract}




\section{Introduction}

The issue of energy use and associated greenhouse gas (GHG) emissions from air transportation has traditionally focused on fuel combustion. Accordingly, most of the efforts to improve the environmental performance of aircraft have been in making them more efficient in flight through lightweighting, improving combustion efficiency or gearing ratios in engines, or redesigning wing aerodynamics (Greene, 1992). Aerospace companies have also begun to target embodied energy and associated greenhouse gas emissions as important environmental indicators. Public reporting is increasingly common, and the International Aerospace Environmental Group has released preliminary guidance on how aerospace companies should measure and report GHG emissions (IAEG, 2013).

Modern aircraft are technological marvels, relying on advanced materials and thousands of precisely engineered components. The most energy and carbon-intensive materials in aircraft are found in the engines. Turbine blades and other engine components must operate flawlessly in an extremely challenging technological environment with high shear forces and temperatures. Because of a zero tolerance for failure, engine components are manufactured to high precision with high-purity materials, many of which are expensive and/or limited in their market size. For these same reasons, secondary (recycled) metals have rarely been used due to impurity risk. However, not reusing the alloys in engine components also means that engine producers must secure long-term contracts for the primary (virgin) supply of these metals from suppliers, and markets that can be subject to geopolitical instability, natural hazards, or price volatility (Alonso et al., 2007). The concept of metal criticality captures these supply risks, such as how essential a metal is to a certain technology (engine components in this case), without technologically suitable substitutes, as well as environmental risks associated with metal production (Erdmann and Graedel, 2011; Graedel et al., 2012).

\subsection{The Business of Recycling Aerospace Alloys}

Dismantling and recycling demonstrations by individual companies and the formation of the Aircraft Fleet Recycling Association have spurred aerospace metal recycling efforts in recent years (Asmatulu et al., 2013a) and helped to set targets for overall aircraft recycling. A demonstration by Airbus as part of the Process for Advanced Management of End of Life Aircraft (PAMELA) program revealed that $85 \%$ of the total mass of materials in obsolete aircraft could potentially be recycled, led by aluminum alloys (Airbus, 2014). This theoretical level of recycling is far above current rates. A detailed study of aerospace manufacturers in the aviation hub of Wichita, USA, revealed that $20 \%$ of recyclable materials are actually recycled (Asmatulu et al., 2013b)

Engine parts specifically have typically been recycled for their nickel content for inclusion into stainless steels. While nickel and some of the alloying elements from engines confer useful material properties in steels, others do not beneficially contribute, and elements such as copper and tin are considered tramp elements that are detrimental to steels (Reck and Graedel, 2012). Direct, closed-loop recycling of aerospace metals decreases their criticality by providing a local, predictable supply with lower risks of disruption, while reducing costs and avoiding the substantial environmental burdens associated with metal mining and processing (Eckelman et al., 2013). From a resource point of view, switching to a closed-loop recycling system allows the specialty alloys in engine components to be reused in engine components for the specific 
physical characteristics to which they were originally designed. As engines are commonly leased and individually tracked in a clear chain of custody, they are relatively free of contamination and can be a source of revenue for the engine and/or airline companies involved, with post-consumer sales typically to specialty metal recyclers.

Large metal recycling firms process hundreds of separate alloys and there is significant interest in quantifying the environmental benefits of its business, specifically in estimating the avoided GHG emissions associated with closed-loop recycling of each alloy. As the alloys are not downcycled, the avoided emissions will be greater than for scrap recyclers that engage in mixed metal recycling. These measures may serve the company and its business partners as a future basis for monetary or regulatory instruments associated with carbon, as a differentiating characteristic in the highly competitive scrap market, and by demonstrating corporate leadership by understanding the sustainability of its operations in general.

\subsection{Metal Cycles and Global Aviation Scrap}

Metal recycling is driven by market forces, but the supply of scrap aerospace metals is challenging to predict. Airbus projects that over the next 20 years, 40,000 aircraft will come out of service, but it would also be useful to understand how these levels will shift year-to-year, what specific alloys will be present, and the dynamics of scrap generation in other economic sectors that may affect global supplies of aviation-relevant scrap. Anthropogenic metal cycles are an important tool in forecasting scrap supplies and assessing the global stocks and flows of a metal, allowing for a comprehensive snapshot of resource use and serving as a basis for scenario modeling (Chen and Graedel, 2012). Global and/or national metal cycles have been created for several elements used in aerospace alloys, including aluminum (Liu and Müller, 2013), nickel (Reck et al., 2008), chromium (Johnson et al., 2006), cobalt (Harper et al., 2011), tungsten (Harper and Graedel, 2008), copper (Graedel et al., 2004), iron (Wang et al., 2007), and zinc (Graedel et al., 2005), as well as for several alloys including stainless steel (Reck et al., 2010) and brass (Daigo et al., 2009). Metal cycles provide detailed information on the size and spatial allocation of production, use, and recycling flows (Cullen and Allwood, 2013). Such information can be used to calculate a wide variety of resource sustainability indicators such as recycling rates (Reck and Gordon, 2008) or the number of times a metal is cycled through the global economy (Eckelman and Daigo, 2008). Such cycles can be linked with life cycle assessment (LCA) models to show the magnitude and location of multiple environmental impacts associated with anthropogenic metal use, including life cycle energy and water demand, deterioration of air and water quality, or increasing toxicity burdens (Eckelman et al., 2012).

\subsection{Environmental Benefits of Metal Recycling}

Recycling activities require capital and natural resources, but avoid the energy-intensive mining, concentrating, smelting, and refining activities required for primary materials. For this reason, metals can often be recycled or reprocessed for additional uses at environmental and economic costs that are much lower than those for primary metal. A compendium of estimates of energy savings from metals recycling can be found in Eckelman et al. (2013), ranging from 55-98\%, depending on the metal. Similar reductions in water use, air and water emissions, and waste generation also accompany recycling compared to producing virgin materials. Much research domestically and internationally has been devoted to metal recycling, both from the perspective of LCA in quantifying environmental benefits (Classen et al., 2009; Dubreuil et al., 2010) and in 
terms of technological potentials and barriers (Allwood et al., 2010; Gaustad et al., 2012; Reck and Graedel, 2012). The metals industry has made declarations on recycling objectives and principles to guide practices and accounting procedures (Atherton, 2007), and has sponsored extensive research into scrap recycling rates and energy benefits of recycling (Johnson et al., 2008).

Despite considerable recycling potentials, little published work has examined the environmental benefits of recycling in the aerospace industry. Asmatulu et al. (2013b) estimated the energy savings and GHG emissions reductions associated with recycling of materials from manufacturers, covering a broad range aircraft components, electronic equipment, and finishings, but did not include engines nor any non-ferrous metals beyond aluminum and copper. Several of the metals contained in engine components, such as rhenium and tantalum, require more than an order of magnitude more energy to produce than aluminum, with similarly large potential benefits alloy recycling after engines or components become obsolete. The elemental composition of an aerospace alloy obviously affect savings from recycling and substitution for primary metals, but there are very few studies that account for this (c.f. Johnson et al., 2008) . The sorting, cleaning, and processing operations of recycling facilities are seldom included in assessment, in part because measured data are difficult to obtain.

In this work we present an in-depth accounting of energy and environmental savings from recycling of aerospace alloys, covering ten of the most important alloys used in aircraft engines. The present study was carried out in cooperation with a large aerospace metals recycler that has several facilities in the United States and several other countries. These serve as collection and/or processing plants, mostly for aircraft-grade aluminum and nickel-bearing alloys from engine components. Over the past several years, this recycling firm sold much of its alloy scrap directly to the smelters that supply aircraft engine component manufacturers, thus creating a closed-loop recycling system. Here we determine the GHG emissions reductions of such a closed-loop approach to aerospace alloy recycling, providing some of the first estimates for a number of alloys and elements as well as details of energy use and emissions from recycling activities. 


\section{Methods}

The wide variety of aerospace alloys are all combinations of a modest number of individual elements, commonly nickel ( $\mathrm{Ni}$ ) and chromium ( $\mathrm{Cr}$ ), the base metals copper ( $\mathrm{Cu}$ ), iron $(\mathrm{Fe})$, and zinc ( $\mathrm{Zn})$, the light metals aluminum (Al), magnesium (Mg), silicon (Si), and the technological metals cobalt (Co), hafnium (Hf), manganese (Mn), molybdenum (Mo), niobium (Nb), tantalum $(\mathrm{Ta})$, titanium $(\mathrm{Ti})$, tungsten $(\mathrm{W})$, vanadium $(\mathrm{V})$, rhenium $(\mathrm{Re})$, and zirconium $(\mathrm{Zr})$.

The project took the following steps in order to quantify the life cycle GHG emissions reductions associated with aerospace alloy recycling:

1. Determine the elemental composition of representative alloys;

2. Quantify the energy use and GHG emissions associated with producing each metal from primary ore;

3. Investigate any technological differences in alloy foundries between melts with all primary metal and melts with some recycled secondary metal and adjust factors as appropriate;

4. Evaluate data quality and uncertainty;

5. Quantify the energy use and GHG emissions associated with collecting, sorting, cleaning, and other processing of the alloy scrap;

6. Subtract the GHGs emitted during secondary processing (step 5) from the GHGs avoided (step 2), to determine the net carbon benefits of recycling the alloy.

All GHG emissions were accounted using $\mathrm{GWP}_{100}$ factors (IPCC, 2007) and reported in units of carbon dioxide equivalents $\left(\mathrm{CO}_{2} \mathrm{e}\right)$.

\subsection{Determine the elemental composition of major aerospace alloys}

There are hundreds of metal alloys employed by the global aerospace industry. Some, such as Inconel 718, are used widely across the industry, while others may be specifically engineered and used only by a single company. Here we examine ten alloys, namely Incoloy 801, Hastelloy C, Waspaloy, RENE 41 and 142, Inconel 718, MAR-M 509, stainless steel AISI/ANSI-316 (EN 1.4401), Ti 6-4, and aircraft grade Aluminum 7075 (Figure 3a), which are representative of the most important classes of metal scrap in aerospace industry recycling. Elemental compositions were determined from alloy specification sheets (MatWeb, 2014) (tabular data provided in Table S1 of the Supplemental Information).

\subsection{Quantify energy/ GHG emissions from producing each element from primary ore}

The production of virgin metal is an enormous industrial undertaking, generally including the major steps of mining, mineral processing/concentrating, and refining. At each stage, impurities are separated and removed and the concentration of metal in the final product increases. For example, platinum group metals that start out at an ore grade (or geologic concentration) of $0.1 \%$ may be processed into metal with a final purity requirement of $99.9 \%$. Refining metals to this level of purity requires repeated, precisely controlled melting and high levels of energy use and associated greenhouse gas emissions, which is a primary reason for the high cost of these 
materials. GHG emissions arise in the metals sector through direct use of fuels, fugitive emissions from minerals processing, or indirectly through the use of electricity, land, infrastructure, and other materials.

GHG emissions from metal production begin with mining, and take many forms. Emissions arise from land clearing and from carbon stored in soils that are also cleared away as overburden, explosives, heavy machinery, heat used for drying or concentration, and electricity to run various pumps, mills, and other pieces of machinery.

Once metal ores have been mined and suitably processed, the minerals they contain are physically or chemically transformed using a variety of technologies (Boldt, 1967).

Pyrometallurgy involves heating of metal concentrates at high temperatures, in order to strip the metal from its associated mineral constituents; this process requires combusting fossil fuels for heating furnaces or electricity to power an electric arc furnace, which carries a high burden of GHG emissions. Thermal decomposition or reduction of carbonate ores will also lead to carbon dioxide emissions. Hydrometallurgy consists of treating ores or concentrates to liquid solutions in order to separate metals from other mineral constituents. Leaching does not necessarily take place at high temperature, but can require high pressures, such as the high-pressure acid leaching process for nickel laterite ores, which requires energy to maintain. Further refining typically follows using electrochemical processes, although some diesel and other fuels may also be used.

\subsubsection{Existing Life Cycle Inventory Data}

There has been much past research on energy use and environmental impacts of metals production, which has tended to focus on the major industrial metals. These results can be found in individual articles and reports, or aggregated in various life cycle inventory databases, which detail the energy and material inputs to and emissions from various industrial processes. Table 1 lists the various databases that were investigated as part of this project, as well as the metals that were included in each.

Table 1 Metal-related LCI databases

\begin{tabular}{|c|c|c|}
\hline Database & Aerospace Metals Included & Reference \\
\hline CCaLC v2.0 & $\mathrm{Al}, \mathrm{Cu}, \mathrm{Fe}, \mathrm{Zn}$ & http://www.ccalc.org.uk/ \\
\hline ecoinvent v2.2 & $\begin{array}{l}\text { Al, Co, Cr, Cu, Fe, Mg, Mn, Mo, Ni, } \\
\text { Si, Ta, Ti, Zn, Zr }\end{array}$ & http://www.ecoinvent.ch/ \\
\hline EIME & $\mathrm{Al}, \mathrm{Cr}, \mathrm{Cu}, \mathrm{Fe}, \mathrm{Mg}, \mathrm{Ni}, \mathrm{Si}, \mathrm{Ti}, \mathrm{W}, \mathrm{Zn}$ & http://www.codde.fr/ \\
\hline ELCD & $\mathrm{Al}, \mathrm{Cu}, \mathrm{Fe}, \mathrm{Zn}$ & http://lct.jrc.ec.europa.eu/assessment/data \\
\hline GaBi & $\begin{array}{l}\text { Al, } \mathrm{Co}, \mathrm{FeCr}, \mathrm{Cu}, \mathrm{Fe}, \mathrm{Mg}, \mathrm{Mn}, \mathrm{Ni}, \mathrm{Si} \\
\text { Ti, Zn, several stainless steel alloys }\end{array}$ & http://www.gabi-software.com/databases/ \\
\hline GHGenius & $\mathrm{Al}, \mathrm{Cu}, \mathrm{Fe}, \mathrm{Ni}, \mathrm{Ti}, \mathrm{Zn}$ & http://www.ghgenius.ca/ \\
\hline $\begin{array}{l}\text { Granta Material } \\
\text { Universe }\end{array}$ & [all elements, aggregated results] & http://www.grantadesign.com/products/ces/ \\
\hline GREET & $\begin{array}{l}\mathrm{Al}, \mathrm{Co}, \mathrm{Cr}, \mathrm{Cu}, \mathrm{Fe}, \mathrm{Mg}, \mathrm{Mn}, \mathrm{Ni}, \mathrm{Ti}, \mathrm{Zn}, \\
\mathrm{Zr}\end{array}$ & http://greet.es.anl.gov/ \\
\hline
\end{tabular}




\begin{tabular}{l|l|l}
\hline IDEMAT 2001 & $\begin{array}{l}\mathrm{Al}, \mathrm{Cr}, \mathrm{Co}, \mathrm{Cu}, \mathrm{Mg}, \mathrm{Mn}, \mathrm{Mo}, \mathrm{Ni}, \mathrm{Ta}, \\
\mathrm{Ti}, \mathrm{V}, \mathrm{W}, \mathrm{Zn}\end{array}$ & http://www.idemat.nl/ \\
\hline Spine@CPM & $\mathrm{Al}, \mathrm{Cu}, \mathrm{Fe}, \mathrm{Si}, \mathrm{Zn}$ & http://cpmdatabase.cpm.chalmers.se/ \\
\hline ProBas & $\begin{array}{l}\mathrm{Al}, \mathrm{Co}, \mathrm{Cr}, \mathrm{Cu}, \mathrm{Fe}, \mathrm{Mg}, \mathrm{Mn}, \mathrm{Mo}, \mathrm{Ni}, \\
\mathrm{Si}, \mathrm{Ta}, \mathrm{Ti}, \mathrm{Zn}\end{array}$ & $\begin{array}{l}\text { http://www.probas.umweltbundesamt.de/php } \\
\text { /index.php }\end{array}$ \\
\hline $\begin{array}{l}\text { University of } \\
\text { Bath ICE v2.0 }\end{array}$ & $\begin{array}{l}\mathrm{Al}, \mathrm{Cu}, \mathrm{Fe}, \mathrm{Cr}, \mathrm{Mn}, \mathrm{Mo}, \mathrm{Ni}, \mathrm{Si}, \mathrm{Ti}, \mathrm{V}, \\
\mathrm{Zn}, \mathrm{Zr}\end{array}$ & $\begin{array}{l}\text { http://www.bath.ac.uk/mech- } \\
\text { eng/sert/embodied/ }\end{array}$ \\
\hline $\begin{array}{l}\text { U.S. LCI } \\
\text { Database }\end{array}$ & $\mathrm{Al}, \mathrm{Cu}, \mathrm{Fe}$ & http://www.nrel.gov/lci/ \\
\hline
\end{tabular}

\subsubsection{New life cycle inventory data}

Several metals that are included in the present study, including niobium, rhenium, tungsten, and zirconium, did not have robust LCI data in current databases that we could find. Therefore, we estimated energy use and GHG emissions factors based on company data, literature sources, and government statistics, as detailed in the Supplemental Information. While these factors are estimates and not primary data that have been validated at metallurgical facilities, they are among the first estimates of GHG emissions intensity for these elements that are not simply proxy values from other metals. A short summary for each element is given here. Niobium production was modeled based on an adapted industrial process description for ferroniobium (Albrecht et al., 2000) by aluminothermic reduction of pyrchlore (niobium oxide) ore. This was checked against information provided by two of the largest producers, CBMM and IAMGOLD and an older estimate from the early 1990s (Paschen, 1993). Rhenium production from molybdenum roaster dust was modeled by re-allocating the ecoinvent record for molybdenum and assuming a byproduct stream of crystallized ammonium perrhenate (Millensifer, 2000). GHG emissions from tungsten production were estimated based on existing energy intensity estimates (Goldwitz, 2003; Granta Design, 2012; UBA, 2010), combined with energy systems data from each of the five largest producing countries. The estimated LCI data for tungsten, as well as titanium and vanadium, have smaller system boundaries than for the other metals because only energy inputs are considered, but these typically drive GHG emissions for metals (Eckelman et al., 2013). Zirconium and hafnium production were modeled using the existing ecoinvent LCI for zirconium oxide and adding process data for subsequent carbochlorination and Kroll reduction to obtain the metal sponge, followed by vacuum arc melting to create pure metal or alloy ingots (Cardarelli, 2008). Environmental burdens were allocated based on the relative prices of the two metals (Gambogi, 2011).

\subsection{Production data versus alloying inputs}

Thus far in this analysis we have estimated the carbon footprint of primary metal production and secondary scrap collection and processing. The next step in the life cycle for both sources of metal is to melt the metals together into the intended alloy. In this section we investigate whether there is any difference in industry practices between the types of material used in primary and secondary metal melts. This is important because significant amounts of energy may be expended in refining a metal from oxide to metallic forms, for example, but if an alloying smelter actually uses the oxide form, then data for the metallic form would overestimate GHG emissions of the smelter inputs. 
Table 2 Typical forms of primary nonferrous metal inputs into alloyers

\begin{tabular}{|c|c|c|c|c|}
\hline Element & $\begin{array}{l}\text { Typical primary } \\
\text { alloying form }\end{array}$ & This assessment & References & Notes \\
\hline $\mathrm{Al}$ & $\begin{array}{l}\text { Metallic form } \\
(>99 \%)\end{array}$ & Metallic form & Kirk-Othmer & For aircraft-grade aluminum \\
\hline $\mathrm{Cr}$ & Metallic form & Metallic form & $\begin{array}{l}\text { Kirk-Othmer; } \\
\text { USGS }\end{array}$ & \\
\hline Co & Metallic form & Metallic form & Kirk-Othmer & \\
\hline $\mathrm{Cu}$ & Metallic form & Metallic form & Kirk-Othmer & $\begin{array}{l}\text { Superalloy Cu is specified to have } \\
\text { high electrical conductivity; typical } \\
\text { starting ingots of fire-refined or } \\
\text { electrolytic-grade } \mathrm{Cu}\end{array}$ \\
\hline $\mathrm{Hf}$ & Metallic form & Metallic form & $\begin{array}{l}\text { Kirk-Othmer; } \\
\text { USGS }\end{array}$ & \\
\hline Mn & Metallic form & $\begin{array}{l}\text { Metallic form } \\
\quad \text { (>98\%) }\end{array}$ & Kirk-Othmer & $\begin{array}{l}\text { Its principal use in the metallic form } \\
\text { is as an alloying element and } \\
\text { cleansing agent for steel, cast iron, } \\
\text { and non-ferrous metals }\end{array}$ \\
\hline Mo & Molybdic oxide & Metallic form & $\begin{array}{l}\text { Kirk-Othmer; } \\
\text { USGS }\end{array}$ & $\begin{array}{l}\text { Molybdenum is added to steels in } \\
\text { the form of molybdic oxide for iron; } \\
\text { Steel and superalloy producers } \\
\text { accounted for about } 75 \% \text { of the } \\
\text { molybdenum consumed }\end{array}$ \\
\hline $\mathrm{Ni}$ & Metallic form & $\begin{array}{l}\text { Metallic form } \\
\text { (Class I, >99\%) }\end{array}$ & Kirk-Othmer & \\
\hline $\mathrm{Nb}$ & $\begin{array}{l}\text { Niobium oxide, } \\
\text { Ferroniobium, } \\
\text { Nickelniobium } \\
\end{array}$ & Ferroniobium & $\begin{array}{l}\text { Kirk-Othmer; } \\
\text { USGS }\end{array}$ & $\begin{array}{l}\text { Superalloys use a pure } \mathrm{NbO}_{2} \text { in pig } \\
\text { heats, or vacuum-grade } \mathrm{FeNb} \text { or } \\
\mathrm{NiNb} \text { as inputs into an alloy melt }\end{array}$ \\
\hline $\operatorname{Re}$ & $\begin{array}{l}\text { Ammonium } \\
\text { perrhenate }\end{array}$ & $\begin{array}{c}\text { Ammonium } \\
\text { perrhenate }\end{array}$ & Kirk-Othmer & $\begin{array}{l}\text { Rhenium for alloy production is in } \\
\text { pelletized form, from powder } \\
\text { production via } \mathrm{NH}_{4} \mathrm{ReO}_{4} \text { reduction }\end{array}$ \\
\hline $\mathrm{Si}$ & $\begin{array}{c}\text { Metallurgical Si } \\
(>95 \%)\end{array}$ & $\begin{array}{c}\text { Metallurgical Si } \\
(>95 \%)\end{array}$ & Classen et al. & Typically alloyed with Al \\
\hline Ta & Tantalum oxide & $\begin{array}{l}\text { Capacitor-grade } \\
\text { tantalum powder }\end{array}$ & Kirk-Othmer & $\begin{array}{l}\text { Oxide used produce such } \\
\text { components as capacitors and or } \\
\text { superalloys }\end{array}$ \\
\hline $\mathrm{Ti}$ & Metallic form & Metallic form & $\begin{array}{l}\text { Kirk-Othmer; } \\
\text { TIMET }\end{array}$ & $\begin{array}{l}\text { Titanium sponge from rutile ore } \\
\text { processing }\end{array}$ \\
\hline $\mathrm{W}$ & $\begin{array}{l}\text { Tungsten carbide; } \\
\text { Metallic form }\end{array}$ & Metallic form & $\begin{array}{l}\text { Kirk-Othmer; } \\
\text { USGS }\end{array}$ & $\begin{array}{l}\text { Forms intermetallic compounds } \\
\left.\text { (e.g., } \mathrm{Co}_{3} \mathrm{~W}\right) \text { and carbides }\end{array}$ \\
\hline $\mathrm{V}$ & $\begin{array}{l}\text { Vanadium } \\
\text { pentoxide }\end{array}$ & Metallic form & Kirk-Othmer & $\begin{array}{l}\text { Conversion of fused pentoxide to } \\
\text { alloy additives is by far the largest } \\
\text { use of vanadium compounds }\end{array}$ \\
\hline $\mathrm{Zr}$ & Metallic form & Metallic form & Kirk-Othmer & \\
\hline
\end{tabular}

Sources: Kirk-Othmer Encyclopedia of Chemical Technology (Kirk-Othmer Encyclopedia of Chemical Technology, 2011); USGS Mineral Commodity Summaries (USGS, 2011); Classen et al. (2009), and TIMET Corporation (http://www.timet.com/index_new.htm) 
Information collated in Table 2 reveals that the metal form used by primary alloyers matches the form specified in our life cycle inventory data, with a few exceptions. First, alloyers use molybdenum oxide $\left(\mathrm{MoO}_{2}\right)$, but the emissions factors available in the ecoinvent database are for metallic molybdenum (assumed thus far) and for molybdenite $\left(\mathrm{MoS}_{2}\right)$. Classen et al. (2009) recommend using life cycle inventory data for molybdenite instead of metallic molybdenum when considering alloying processes, but this still does not accurately represent the oxide input actually used by alloyers. The roasting process that generates the dust source for rhenium also produces a molybdenum oxide calcine (see Figure S19 in the Supplement). The factor for the oxide chemical form is $3.6 \mathrm{~kg} \mathrm{CO} 2 \mathrm{e} / \mathrm{kg} \mathrm{MoO}_{2}$, or $4.8 \mathrm{~kg} \mathrm{CO}_{2} \mathrm{e} / \mathrm{kg}$ on a contained-Mo basis. The two other possible inconsistencies that arise from Table 2 are that tantalum powder produced for capacitors has slightly different processing routes than that produced for alloys (Classen et al., 2009), and that vanadium metal is more commonly employed by alloyers versus the vanadium oxide assumed here, but given the lack of additional inventory data, the current emission factors were deemed to be sufficiently representative.

\subsection{Uncertainty analysis and parameter estimation}

Monte Carlo simulation was carried out to provide error bounds on the results separately for primary metals and for alloys. First, LCI data from existing datasets and calculations were entered into SimaPro and their distribution parameters calculated using the Pedigree matrix (Frischknecht and Jungbluth 2007; Weidema and Wesnæs 1996). Although several datasets exist for many of the more commonly used elements, for internal consistency, the ecoinvent 2.2 LCI database was used as the preferred source (Althaus et al., 2007; Classen et al., 2009), as these datasets are the most transparent and cover most of the metals of interest. Once all of the process inputs had been assigned associated lognormal distribution parameters, each element was analyzed using the internal Monte Carlo simulation algorithm in SimaPro 7.3.3 (1000 runs), to obtain a distribution of GHG emissions factors. Curve-fitting with Kolmogorov-Smirnof statistics was used to estimate distribution parameters for the best fit distribution and the lognormal distribution. Summary GHG emissions factors calculated from the elemental Monte Carlo assessment and adopted for the present study are listed in Table 3, including adjustments for actual remelter inputs. (Summary graphs for each element are provided in the Supplemental Information.)

Next, random sampling from lognormal distributions for each element were combined with the elemental composition for each alloy in a Monte Carlo simulation (1000 runs) to generate a distribution of GHG emission factors for each alloy. $5^{\text {th }}$ and $95^{\text {th }}$ percentiles were calculated and included in the results (Figure 3b). Additionally, data quality indicators was compiled for each of the alloying elements, showing spatial and temporal information whether proxy energy data were used, and if price allocation was performed (Table S2 in the Supplemental Information). 
Table 3 GHG emissions factors for aerospace metals in $\mathrm{kg} \mathrm{CO}_{2} \mathrm{e}$ per kg of metal and lognormal distribution parameters

\begin{tabular}{|c|c|c|c|c|c|}
\hline \multirow[b]{2}{*}{ Element } & \multicolumn{2}{|c|}{$\begin{array}{l}\text { Absolute Emissions } \\
\left(\mathrm{kg} \mathrm{CO}_{2} \mathrm{e} / \mathrm{kg}\right)\end{array}$} & \multicolumn{2}{|c|}{$\begin{array}{c}\text { Lognormal Distribution } \\
\text { (Fitted) Parameter Values }\end{array}$} & \multirow[t]{2}{*}{ Primary Source } \\
\hline & mean & std. dev. & $\mu$ & $\sigma$ & \\
\hline Al & 12.2 & 1.1 & 2.5 & 0.09 & ecoinvent 2.2 \\
\hline Co & 8.3 & 1.4 & 2.10 & 0.16 & ecoinvent 2.2 \\
\hline $\mathrm{Cr}$ & 26.7 & 2.6 & 3.28 & 0.10 & ecoinvent 2.2 \\
\hline $\mathrm{Cu}$ & 3.1 & 0.4 & 1.13 & 0.09 & ecoinvent 2.2 \\
\hline $\mathbf{F e}$ & 1.5 & 0.1 & 0.42 & 0.04 & ecoinvent 2.2 \\
\hline Hf & 169 & 56 & 3.06 & 0.31 & [calculation] \\
\hline Mg & 73.7 & 55 & 4.10 & 0.62 & ecoinvent 2.2 \\
\hline Mn & 2.6 & 0.4 & 0.93 & 0.17 & ecoinvent 2.2 \\
\hline Mo ${ }^{*}$ & 4.8 & 3.2 & 2.16 & 0.33 & ecoinvent 2.2 \\
\hline $\mathrm{Nb}^{*}$ & 7.1 & 1.1 & 1.96 & 0.16 & [calculation] \\
\hline $\mathrm{Ni}$ & 10.9 & 0.6 & 2.38 & 0.06 & ecoinvent 2.2 \\
\hline $\mathbf{R e}$ & 290 & 100 & 5.60 & 0.34 & [calculation] \\
\hline Si & 5.0 & 0.2 & 1.61 & 0.04 & ecoinvent 2.2 \\
\hline $\mathbf{T a}$ & 260 & 33 & 5.55 & 0.12 & ecoinvent 2.2 \\
\hline $\mathbf{T i}$ & 45.1 & 7.5 & 3.80 & 0.16 & IDEMAT \\
\hline V & 33.1 & 8.7 & 3.47 & 0.26 & IDEMAT \\
\hline $\mathbf{W}$ & 12.6 & 1.8 & 2.52 & 0.14 & [calculation] \\
\hline Zn & 3.2 & 0.5 & 1.16 & 0.15 & ecoinvent 2.2 \\
\hline $\mathbf{Z r}$ & 22.3 & 7.3 & 3.06 & 0.31 & [calculation] \\
\hline
\end{tabular}

Notes: * $\mathrm{MoO}_{2}$ on a contained-Mo basis; the factor for metallic Mo is $9.2 \mathrm{~kg} \mathrm{CO} 2 \mathrm{e} / \mathrm{kg}$; $\mathrm{Nb}$ as FeNb 


\section{Quantify the energy use and GHG emissions associated with collecting, sorting, cleaning, and otherwise processing of the alloy scrap}

In this section, we detail the emissions associated with all recovery and recycling processes, as carried out by the recycling corporation. Energy use and GHG emissions were collected on site over a period of several months during the summer of 2011. The carbon footprint included emissions of carbon dioxide, methane, and nitrous oxide, and followed the internationally standardized GHG Protocol (WRI/WBCSD, 2004). In this standard, emissions are separated into three categories, or "scopes", as follows:

- Scope 1 - Emissions from direct fuel use on-site or from company owned vehicles;

- Scope 2 - Emissions from purchased energy, primarily electricity; and

- Scope 3 - Remaining sources of emissions, including contractor vehicles and processing by contractors, waste management, and supply-chain emissions.

Table 4 shows company-wide emissions by scope and source. The largest source of emissions by far was the collection or transport of scrap material by truck, either using company-owned vehicles or those owned by contractors. Smaller quantities of emissions arose from stationary combustion (for heating the facilities), diesel and propane equipment (such as forklifts), and purchased electricity (for running sorting and crushing machines, as well as auxiliary equipment and lights).

Table 42010 GHG emissions from SOS Metals global operations, by source

\begin{tabular}{lrrrr} 
Emission Source & $\mathbf{C O}_{2}(\mathrm{t})$ & $\mathbf{C H}_{4}(\mathrm{~kg})$ & $\mathbf{N}_{\mathbf{2}} \mathbf{O}(\mathrm{kg})$ & $\mathbf{C O}_{\mathbf{2}} \mathbf{e}(\mathrm{t})$ \\
\cline { 2 - 6 } SCOPE 1 & & & & \\
$\quad$ Stationary combustion (natural gas) & 66 & 3.6 & 0.1 & 67 \\
$\quad$ Road transport (diesel truck) & 1,690 & 2.5 & 2.4 & 1,694 \\
Off-road diesel equipment & 145 & 8.3 & 3.7 & 146 \\
$\quad$ Propane equipment & 243 & 21 & 0.4 & 243 \\
$\quad$ Refrigerants & $n / a$ & $n / a$ & $n / a$ & 6 \\
\hline SCOPE 2 & 561 & 16.4 & 7.0 & 563 \\
$\quad$ Purchased electricity & $\mathbf{2 , 7 0 5}$ & $\mathbf{5 1 . 2}$ & $\mathbf{1 3 . 6}$ & $\mathbf{2 , 7 2 0}$ \\
\hline$\quad$ SCOPES 1-2 Subtotal & & & & \\
\hline SCOPE 3 & 919 & 2.8 & 2.6 & 920 \\
Contractor vehicles: Domestic (truck) & 57 & 0.2 & 0.2 & 57 \\
Contractor vehicles: International (truck) & 53 & 4.2 & 1.4 & 54 \\
Contractor vehicles: International (rail) & 12 & 9.9 & 0.3 & 12 \\
Contractor vehicles: International (ship) & 44 & 1.8 & 0.4 & 44 \\
$\quad$ Processing by contractors (BD\&G) & 62 & 3.4 & 0.4 & 63 \\
$\quad$ Processing by contractors (cleaning) & $\mathbf{1 , 1 4 7}$ & $\mathbf{2 2 . 3}$ & $\mathbf{5 . 3}$ & $\mathbf{1 , 1 5 0}$ \\
\hline$\quad$ SCOPE 3 Subtotal & $\mathbf{3 , 8 5 2}$ & $\mathbf{7 3 . 5}$ & $\mathbf{1 8 . 9}$ & $\mathbf{3 , 8 7 0}$ \\
\hline$\quad$ SCOPES 1-3 TOTAL & &
\end{tabular}

Scope 3 sources of GHG emissions that are not directly related to processing the scrap metal, such as employee travel, are omitted from this analysis. 
The numbers presented in Table 4 reflect 2010 GHG emissions for the entire company. In order to compare with emissions from primary production on a per kg basis, we downscaled these total emissions to individual alloys. This was done in two steps: from corporation to facility and from facility to alloy, as different facilities collect and processes different mixes of alloys.

First, we divided the total amount of emissions from each facility by the total sales (on monetary and weight bases) from those facilities. Figure 1 shows the per unit emissions for each facility, as well as the US and world averages. The corporation's largest processing facility had the lowest per unit emissions, likely due to the high levels of throughput and low heating requirements in its location. By far the most carbon-intensive facility is one where large amounts of propane are used for heating and the total throughput of the facility (the denominator in the carbon intensity calculation) is relatively low.

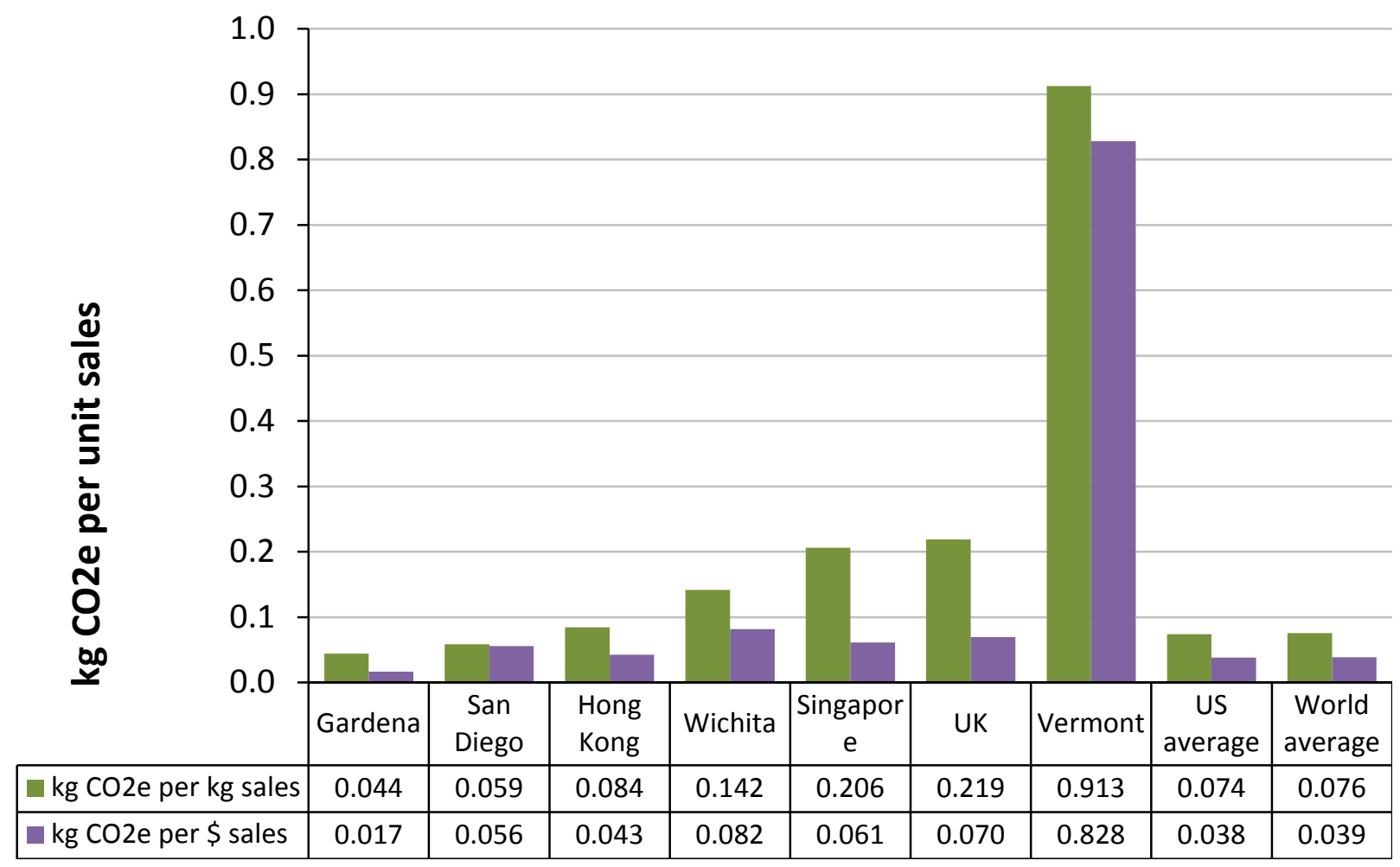

Figure 1 Carbon intensity of metals processing in different recycler facilities

Second, the carbon intensity of each facility was assigned to the mix of alloys processed there, as different facilities specialize in different types of scrap. Figure 2 shows corporate sales for eight classes of metal broken down by mass and by economic value. The figure reveals relatively low revenue generated by sales of steel despite its large quantity, versus the significant revenues from $\mathrm{Ni} / \mathrm{Co}$ alloys that are processed in relatively small quantities. So, using economic allocation, $\mathrm{Ni} / \mathrm{Co}$ alloys have a relatively high carbon intensity of processing compared to steels. As the sale price per unit of metal drives economic decisions in the primary and secondary metal industries, LCA guidelines recommend that allocation of greenhouse gas emissions be done on the basis of economic value (Althaus and Classen, 2005). Table 5 shows the final GHG emission results for the scrap processing operations and compares the two allocation methods for each 
major scrap type. It is important to note that the field LCI data collected for recycled metals do not have exactly the same system boundaries as the largely ecoinvent data for primary metals-specifically, capital equipment and building infrastructure have not been included (though their operation has been)-but these are typically minor categories for GHG emissions (Classen et al., 2009).
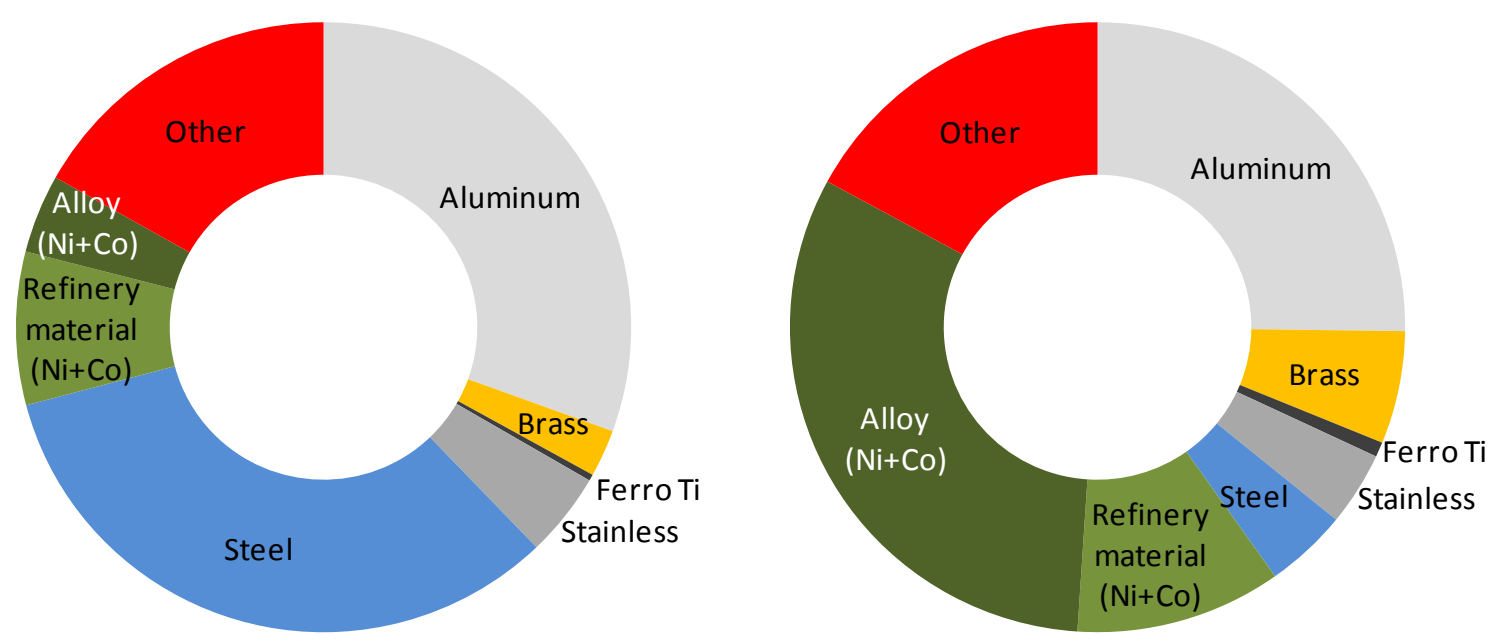

Figure 2 Sales by SOS Metals of processed scrap by alloy by mass (left panel) and economic value (right panel)

Table 5 GHG emissions from scrap collection and processing, SOS Metals

\begin{tabular}{lccccc}
\cline { 2 - 6 } & \multicolumn{5}{c}{ [\% change, } \\
& $\begin{array}{c}\text { [by mass] } \\
\text { kg CO2e } \\
\text { per kg } \\
\text { metal }\end{array}$ & $\begin{array}{c}\text { kg CO2e } \\
\text { per \$ }\end{array}$ & $\begin{array}{c}\text { price, } \\
\text { \$/kg metal }\end{array}$ & $\begin{array}{c}\text { kg CO2e } \\
\text { per kg metal }\end{array}$ & +/- \% \\
\hline Aluminum & 0.098 & 0.056 & 1.61 & 0.090 & -8 \\
Brass & 0.053 & 0.040 & 4.64 & 0.187 & +251 \\
Ferro Ti & 0.061 & 0.033 & 4.59 & 0.152 & +150 \\
Stainless steel & 0.063 & 0.034 & 1.71 & 0.057 & -9 \\
Steel & 0.061 & 0.039 & 0.26 & 0.010 & -84 \\
Refinery (Ni+Co) & 0.049 & 0.024 & 2.60 & 0.062 & +26 \\
Alloy (Ni+Co) & 0.052 & 0.021 & 14.88 & 0.308 & +496 \\
Other & 0.071 & 0.048 & 1.97 & 0.095 & +34 \\
Metal average & $\mathbf{0 . 0 7 2}$ & $\mathbf{0 . 0 3 7}$ & $\mathbf{1 . 9 5}$ & $\mathbf{0 . 0 7 2}$ & \\
\hline
\end{tabular}




\section{Alloy Results and Discussion}

Based on the steps detailed in Section 3, the net environmental benefits of recycling for each alloy can now be calculated. First, GHG emissions from producing each alloy were determined by simply multiplying the proportion of each element in the alloy by the GHG emissions factor for that element, summing them to a total amount for the alloy.

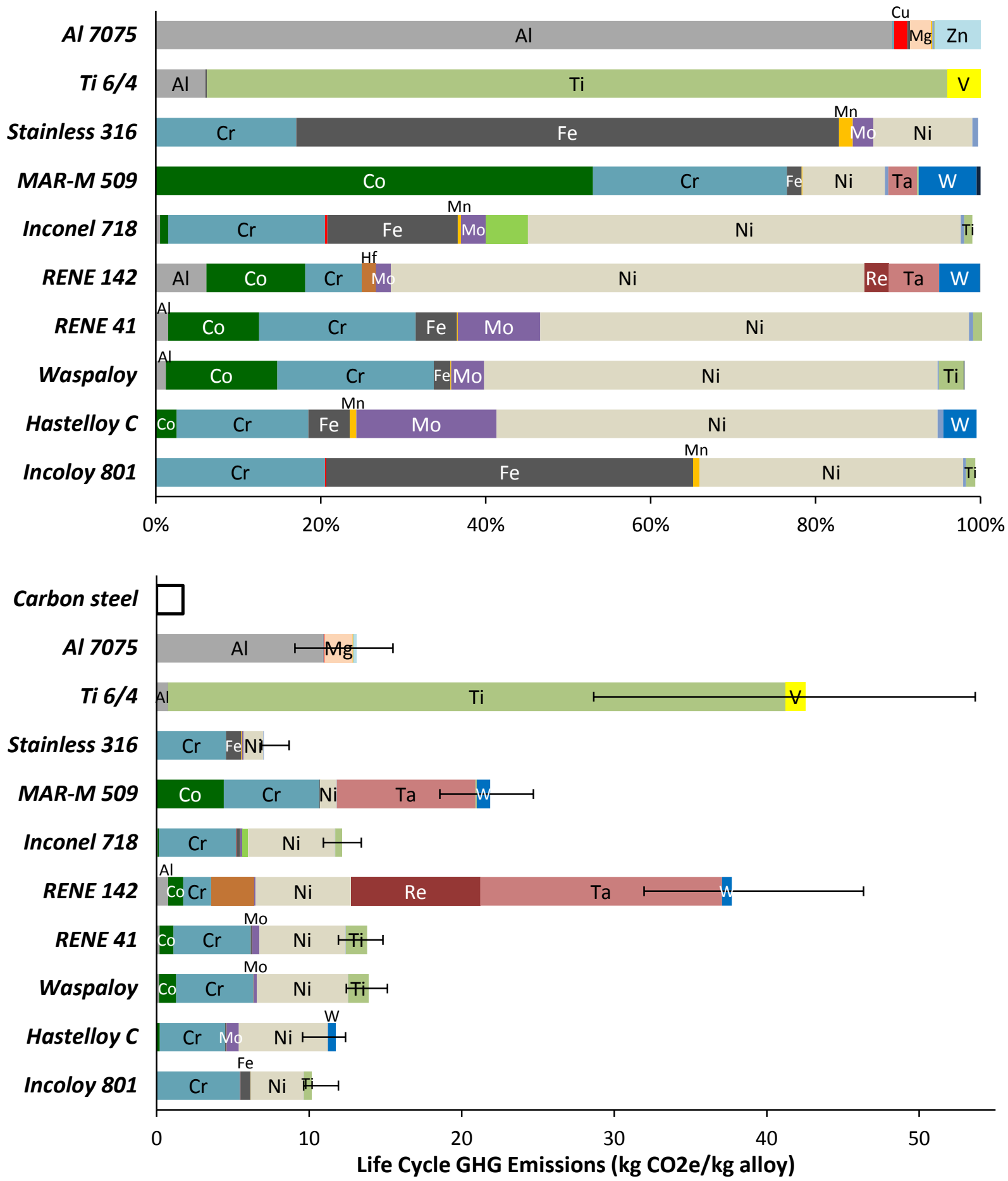

Figure 3 Elemental contribution to alloy composition (a, top) and GHG emissions (b, bottom) for ten aerospace alloys. Low-alloyed steel is presented in the bottom chart for comparison (ecoinvent 2.2). 
Figure 3 depicts the relative contribution of each element to the composition of the ten alloys, and the final GHG emissions per kg of alloy produced. The ten alloys in question have quite different hotspots in their life cycle GHG emission profiles. Certain elements occur in small quantities in some alloys, such as rhenium $(\mathrm{Re})$ and tantalum $(\mathrm{Ta})$, but due to their high carbon intensity they are very significant in the final results. Stainless 316 has by far the lowest associated GHG emissions, with $6.0 \mathrm{~kg} \mathrm{CO}{ }_{2} \mathrm{e} / \mathrm{kg}$, while the emissions factor for RENE 142 is more than six times as high. On an economic basis, $\mathrm{Ni}+\mathrm{Co}$ superalloys fetch nearly nine times as much in secondary markets as stainless steels, and so targeting these alloys for collection is both financially and environmentally beneficial. Recycling of Ti 6/4 results in the largest GHG emissions reductions by mass, but the market value of these alloys is only $\sim 30 \%$ that of $\mathrm{Ni}+\mathrm{Co}$ superalloys. Overall, the recycling of aerospace alloys for reuse in the aerospace industry represents significant reductions in GHG emissions for all of the alloys considered.

Recycling each alloy avoids the emissions for primary alloy production shown in Figure 3b. Net GHG savings or emissions reductions are estimated by using the results in Figure 3b and subtracting the positive emissions that occur during scrap processing (Table 5). It is important to note that these emissions from recycling operations are relatively insignificant (0.4-3.2\%) compared to the emissions reductions from substitution. This indicates that efficient aerospace recyclers can act as carbon-negative businesses if they are given credit for avoiding GHG emissions from primary metal production; however, significant debate exists around which business entities in the secondary production chain should claim responsibility for reducing emissions. The metals industry prefers that reductions be assigned to entities that generate, collect, and process the scrap (using 100-0 allocation in open-loop recycling) rather than to buyers of recycled-content metals (0-100 allocation) (Atherton, 2007). In this case where alloys are being kept in a closed-loop cycle and the supplier of aerospace scrap is identical to the purchaser of secondary alloys, these allocation schemes are essentially the same.

These results show the effect of substituting aerospace scrap for primary metal, but do not consider the substitution that occurs in more common downcycling practices where specific elements within an alloy are typically targeted for recycling. In these cases, substitution of primary metal still takes place, just not for all elements in the aerospace alloy. Nickel and chromium units are valued in stainless steel recycling. For those alloys with significant $\mathrm{Ni}$ and $\mathrm{Cr}$ (Incoloy 801, Hastelloy C, Waspaloy, RENE 41, and Inconel 718), closed-loop recycling offers modest benefits (3-23\% greater reduction in GHG emissions) over downcycling to stainless steels. For superalloys with other significant alloying elements that are not substituted (RENE 142 and MAR-M 509), the benefits of closed-loop recycling over downcycling are much greater (200-360\%). Aerospace alloys have historically been downcycled rather than recycled directly due to concerns of introducing contamination, but advanced techniques for precisely identifying alloys, such as X-ray fluorescence, has greatly reduced these risks. Smelters' reluctance to use recycled metals for sale to aerospace companies has also changed as engine producers and owners realize that they can manage the entire life cycle of these specialty alloys, thereby saving money and reducing supply risks.

Finally, there are several stipulations that should be noted. The GHG emissions from scrap processing reported here reflect just one (albeit large) entity in this sector. Other companies may 
employ different practices or equipment that lead to higher recycling emissions, although these are small relative to the emissions reductions from substitution for primary metal. Where necessary, allocation in this case is less contentious that in other areas of LCA because there is a long-standing preference in the metals industry for economic allocation, which has manifested itself recently in product category rules (PCRs) for basic metals (Scarinci, 2012). Reliance on economic allocation means that changes in relative prices of co-produced metals will produce changes in results, so updating results over time will be important for recyclers relying on this information. The analysis also does not consider price effects from widespread introduction of closed-loop recycling of aerospace alloys, which reduces the amount nickel-bearing scrap supply available for downcycling; however, in the case of stainless steel scrap, the nickel in aerospace scrap is a small fraction of the total and so these effects are expected to be minimal.

\section{Acknowledgements}

The authors thank SOS Metals for financial and project support, and declare no conflict of interest. 


\section{References}

Airbus, 2014. Aircraft End of Life, http://www.airbus.com/innovation/eco-efficiency/aircraftend-of-life/.

Albrecht, S., Cymorek, C., Eckert, J., 2000. Niobium and Niobium Compounds, Ullmann's Encyclopedia of Industrial Chemistry. Wiley-VCH Verlag GmbH \& Co. KGaA.

Allwood, J.M., Cullen, J.M., Cooper, D.R., Milford, R.L., Patel, A.C.H., Carruth, M.A., McBrien, M., 2010. Conserving our Metal Energy. University of Cambridge, Cambridge, UK.

Alonso, E., Gregory, J., Field, F., Kirchain, R., 2007. Material availability and the supply chain: Risks, effects, and responses. Environ Sci Technol 41, 6649-6656.

Althaus, H.-J., Chudacoff, M., Hischier, R., Osses, M., Primas, A., 2007. Life Cycle Inventories of Chemicals. Final Report ecoinvent data v2.1, No.10. Swiss Center for Life Cycle Inventories, Dubendorf, Switzerland.

Althaus, H.J., Classen, M., 2005. Life Cycle Inventories of Metals and Methodological Aspects of Inventorying Material Resources in Ecoinvent. The International Journal of Life Cycle Assessment 10, 43-49.

Asmatulu, E., Overcash, M., Twomey, J., 2013a. Recycling of Aircraft: State of the Art in 2011. Journal of Industrial Engineering 2013.

Asmatulu, E., Twomey, J., Overcash, M., 2013b. Evaluation of recycling efforts of aircraft companies in Wichita. Resources, Conservation and Recycling 80, 36-45.

Atherton, J., 2007. Declaration by the metals industry on recycling principles. The International Journal of Life Cycle Assessment 12, 59-60.

Boldt, J.R., 1967. The winning of nickel: Its geology, mining, and extractive metallurgy. D. Van Nostrand Company, Inc., Princeton, NJ.

Cardarelli, F.o., 2008. Materials Handbook: A Concise Desktop Reference. Springer.

Chen, W.-Q., Graedel, T., 2012. Anthropogenic cycles of the elements: A critical review. Environ Sci Technol 46, 8574-8586.

Classen, M., Althaus, H.-J., Blaser, S., Tuchschmid, M., Jungbluth, N., Doka, G., Faist Emmenegger, M., Scharnhorst, W., 2009. Life Cycle Inventories of Metals. Final Report ecoinvent data v2.1, No.10. Swiss Center for Life Cycle Inventories, Dubendorf, Switzerland.

Cullen, J.M., Allwood, J.M., 2013. Mapping the global flow of aluminum: From liquid aluminum to end-use goods. Environ Sci Technol 47, 3057-3064. 
Daigo, I., Hashimoto, S., Matsuno, Y., Adachi, Y., 2009. Material stocks and flows accounting for copper and copper-based alloys in Japan. Resources, Conservation and Recycling 53, 208217.

Dubreuil, A., Young, S.B., Atherton, J., Gloria, T.P., 2010. Metals recycling maps and allocation procedures in life cycle assessment. The International Journal of Life Cycle Assessment 15, 621634.

Eckelman, M.J., Daigo, I., 2008. Markov chain modeling of the global technological lifetime of copper. Ecological Economics 67, 265-273.

Eckelman, M.J., Mudd, G.M., Norgate, T.E., 2013. Metals and Energy, in: van der Voet, E. (Ed.), Environmental Impacts of Metals. UNEP Resource Panel.

Eckelman, M.J., Reck, B.K., Graedel, T., 2012. Exploring the global journey of nickel with Markov chain models. Journal of Industrial Ecology 16, 334-342.

Erdmann, L., Graedel, T.E., 2011. Criticality of non-fuel minerals: a review of major approaches and analyses. Environ Sci Technol 45, 7620-7630.

Gambogi, J., 2011. Zirconium and Hafnium, 2010 Minerals Yearbook. U.S. Geological Service (USGS).

Gaustad, G., Olivetti, E., Kirchain, R., 2012. Improving aluminum recycling: A survey of sorting and impurity removal technologies. Resources, Conservation and Recycling 58, 79-87.

Goldwitz, J.A., 2003. Batchelor's Thesis in Mechanical Engineering. Massachusetts Institute of Technology, Cambridge, MA.

Graedel, T., Barr, R., Chandler, C., Chase, T., Choi, J., Christoffersen, L., Friedlander, E., Henly, C., Jun, C., Nassar, N.T., 2012. Methodology of metal criticality determination. Environ Sci Technol 46, 1063-1070.

Graedel, T., Beers, D., Bertram, M., Fuse, K., Gordon, R.B., Gritsinin, A., Harper, E.M., Kapur, A., Klee, R.J., Lifset, R., 2005. The multilevel cycle of anthropogenic zinc. Journal of Industrial Ecology 9, 67-90.

Graedel, T.E., Van Beers, D., Bertram, M., Fuse, K., Gordon, R.B., Gritsinin, A., Kapur, A., Klee, R.J., Lifset, R.J., Memon, L., Rechberger, H., Spatari, S., Vexler, D., 2004. Multilevel cycle of anthropogenic copper. Environ Sci Technol 38, 1242-1252.

Granta Design, 2012. Granta: CES Selector materials selection software.

Greene, D.L., 1992. Energy-efficiency improvement potential of commercial aircraft. Annual Review of Energy and the Environment 17, 537-573. 
Harper, E., Graedel, T., 2008. Illuminating tungsten's life cycle in the United States: 1975-2000. Environ Sci Technol 42, 3835-3842.

Harper, E., Kavlak, G., Graedel, T., 2011. Tracking the metal of the goblins: Cobalt's cycle of use. Environ Sci Technol 46, 1079-1086.

IAEG, 2013. GHG Reporting Guidance for the Aerospace Industry. International Aerospace Environmental Group (IAEG), http://www.ghgprotocol.org/files/ghgp/Draft_GHG_Reporting_Guidance_for_Aerospace_rev12 clean.pdf.

IPCC, 2007. Integovernmental Panel on Climate Change (IPCC), Fourth Assessment Report.

Johnson, J., Reck, B., Wang, T., Graedel, T., 2008. The energy benefit of stainless steel recycling. Energy Policy 36, 181-192.

Johnson, J., Schewel, L., Graedel, T., 2006. The contemporary anthropogenic chromium cycle. Environ Sci Technol 40, 7060-7069.

Kirk-Othmer Encyclopedia of Chemical Technology, 2011. John Wiley \& Sons, Inc.

Liu, G., Müller, D.B., 2013. Mapping the global journey of anthropogenic aluminum: A tradelinked multilevel material flow analysis. Environ Sci Technol 47, 11873-11881.

MatWeb, 2014. www.matweb.com.

Millensifer, T.A., 2000. Rhenium and Rhenium Compounds, Kirk-Othmer Encyclopedia of Chemical Technology. John Wiley \& Sons, Inc.

Paschen, P., 1993. Energy consumption in the extractive metallurgy of niobium and tantalum. TIC Bulletin 73, 4-7.

Reck, B.K., Chambon, M., Hashimoto, S., Graedel, T., 2010. Global stainless steel cycle exemplifies China's rise to metal dominance. Environ Sci Technol 44, 3940-3946.

Reck, B.K., Gordon, R.B., 2008. Nickel and chromium cycles: Stocks and flows project part IV. JOM 60, 55-59.

Reck, B.K., Graedel, T., 2012. Challenges in metal recycling. Science 337, 690-695.

Reck, B.K., Müller, D.B., Rostkowski, K., Graedel, T.E., 2008. Anthropogenic nickel cycle: Insights into use, trade, and recycling. Environ Sci Technol 42, 3394-3400.

Scarinci, C., 2012. Product Category Rule UNCPC 41413, Copper Cathode "Grade A", 2012:16, version 1.0 . 
UBA, 2010. ProBas - Lebenszyklusdatenbank [Life Cycle Inventory Database]. Umweltbundesamt (German Federal Environmental Agency) and Ã-ko-Institut, Dessau (Germany); Freiburg (Germany).

USGS, 2011. Mineral Commodity Summaries. US Geological Survey, http://minerals.usgs.gov/minerals/pubs/mcs/.

Wang, T., Müller, D.B., Graedel, T., 2007. Forging the anthropogenic iron cycle. Environ Sci Technol 41, 5120-5129.

WRI/WBCSD, 2004. GHG Protocol: A Corporate Accounting and Reporting Standard, Revised Edition. World Resources Institute and World Business Council for Sustainable Development. 